\title{
Justyna Krzywkowska
}

\section{Sprawozdanie z II Międzynarodowej Konferencji Kanonicznego Prawa Procesowego „Problemy z sądową ochroną praw człowieka”, Olsztyn, 7-8 maja 2012 r.}

Ius Matrimoniale 18 (24), 261-270

2013

Artykuł został opracowany do udostępnienia w internecie przez Muzeum Historii Polski w ramach prac podejmowanych na rzecz zapewnienia otwartego, powszechnego i trwałego dostępu do polskiego dorobku naukowego i kulturalnego. Artykuł jest umieszczony w kolekcji cyfrowej bazhum.muzhp.pl, gromadzącej zawartość polskich czasopism humanistycznych i społecznych.

Tekst jest udostępniony do wykorzystania w ramach dozwolonego użytku. 


\section{SPRAWOZDANIE Z II MIĘDZYNARODOWEJ KONFERENCJI KANONICZNEGO PRAWA PROCESOWEGO „PROBLEMY Z SĄDOWĄ OCHRONĄ PRAW CZLOWIEKA” (OLSZTYN, 7-8 MAJA 2012)}

W dniach 7-8 maja 2012 r. na Wydziale Prawa i Administracji Uniwersytetu Warmińsko-Mazurskiego w Olsztynie odbyła się II Międzynarodowa Konferencja Kanonicznego Prawa Procesowego pt. „Problemy z sądową ochroną praw człowieka”. Głównym organizatorem konferencji była Katedra Prawa Kanonicznego i Wyznaniowego WPiA UWM, zaś jej współorganizatorami: Korpus Adwokatów Kościelnych w Polsce, Studenckie Koło Naukowe Prawników Kanonistów UWM, Oddział Okręgowy Katolickiego Stowarzyszenia „Civitas Christiana" w Olsztynie oraz Europejskie Stowarzyszenie Studentów Prawa ELSA.

Zamierzeniem organizatorów tej cyklicznej - odbywającej się co 2 lata - konferencji było przeanalizowanie sądowej ochrony praw człowieka na gruncie norm prawa kanonicznego i norm procesowych obowiązujących w innych systemach prawnych. Obrady odbywające się w Bibliotece Uniwersyteckiej poprzedziła uroczysta Msza św. w intencji pomyślności konferencji, której przewodniczył bp Jacek Jezierski, biskup pomocniczy archidiecezji warmińskiej.

W imieniu wszystkich organizatorów słowo wstępne wygłosił ks. prof. Ryszard Sztychmiler (UWM, KAK), który przywitał licznie przybyłych gości: władze wydziału, które życzliwie wspierały przygotowania do konferencji, przedstawicieli władz świeckich i kościelnych, pracowników naukowych UWM i innych uczelni, autorów referatów z Polski, Austrii, Białorusi, Włoch i Słowacji, zacnych przedstawicieli komitetu honorowego i naukowego z najważniejszych ośrodków myśli kanonistycznej, przewodniczących sesji, sponsorów, studentów oraz słuchaczy. Na konferencji nie zabrakło przedstawiciela Ministerstwa Sprawiedliwości, dra Piotra Jarosa z Departamentu Współpracy Międzynarodowej i Praw Człowieka, dawniejszego Rzecznika Praw Dziecka. Ks. prof. Sztychmiler w przemówieniu podkreślił, że w każdej społeczności człowiek posiada różne uprawnienia, które powinny być uznawane i respektowane; nikt nie powinien dochodzić swych praw przemocą i wymierzać sprawiedliwości według własnego uznania. 
Najlepszą drogą rozwiązania problemu jest zwrócenie się do właściwej instytucji. Szczególne znaczenie w tym kontekście ma sądowa ochrona praw człowieka. Praktyczna realizacja tej ochrony wymaga jednak dostrzeżenia szeregu ewentualnych trudności, wobec których może stanąć podmiot dochodzący swych praw i wolności. Kończąc wystapienie ks. prof. R. Sztychmiler życzył wszystkim owocnych obrad i dobrego samopoczucia na uczelni.

Następnie głos zabrał sekretarz województwa warmińsko-mazurskiego, Janusz Smoliński, który odczytał list od marszałka województwa Jacka Protasa. Podkreślono, że właśnie dzięki takim konferencjom buduje się bezpieczną przyszłość, zwiększa się świadomość społeczną w tym zakresie.

Otwarcia konferencji dokonał prodziekan ds. studiów stacjonarnych, prof. UWM dr hab. Piotr Krajewski. Pan dziekan zwrócił uwagę, że obecnie ochrona praw człowieka narażona jest na różne niebezpieczeństwa, tych zagrożeń jest coraz więcej, dlatego tak ważne jest szukanie sposobów ochronnych tych podstawowych praw człowieka, ich zabezpieczenie na przyszłość.

Następnie głos zabrał dr Paweł Jaros, który w imieniu Ministra Sprawiedliwości i władz Departamentu Współpracy Międzynarodowej i Praw Człowieka przekazał serdeczne gratulacje dla organizatorów. Dr Jaros wskazał, że ochrona praw człowieka to priorytet działalności Ministerstwa Sprawiedliwości. Ważne jest zapewnienie, aby każdy człowiek rzeczywiście mógł dochodzić swoich praw. Ważne jest także upowszechnianie praw człowieka, dlatego m.in. od ok. 3 lat na stronie internetowej Ministerstwa znajdują się tłumaczone wyroki Europejskiego Trybunału Praw Człowieka; Krajowa Rada Sądownictwa organizuje szkolenia; prowadzona jest działalność ustawodawcza w zakresie zmian polskiego prawa (np. realizacja prawa do małżeństwa przez osoby ubezwłasnowolnione, problem ten dotyka rocznie kilku tysięcy osób). Na zakończenie dr Jaros życzył nie tylko sukcesów teoretycznych, ale również tych, które będą miały wymiar praktyczny, by postulaty konferencyjne zapewniły skuteczniejszą ochronę praw człowieka.

Po przerwie kawowej przystapiono do wygłaszania referatów. Obrady podzielone zostały na 5 sesji, które pozwoliły poznać różne aspekty ochrony praw człowieka: w procesach kanonicznych; w procesach cywilnych; w Trybunale Konstytucyjnym oraz w postępowaniu i procesie administracyjnym; w procesach karnych; w procesach 
przed trybunałami międzynarodowymi. Wspólnym filarem łączącym wszystkie sesje było szukanie odpowiedzi na pytanie: Jak usprawnić dochodzenie swoich uprawnień na drodze sądowej? Duże zainteresowanie konferencją świadczy o ważkości tej problematyki. Wygłoszono kilkadziesiąt wykładów. Prelegentami byli wybitni prawnicy z kraju i zagranicy, przedstawiciele licznych uczelni.

Pierwszej sesji pt. „Ochrona praw człowieka w procesach kanonicznych" przewodniczyli ks. prof. zw. dr hab. Wojciech Góralski (część 1) oraz ks. prof. UKSW dr hab. Jan Krajczyński (część 2). Konsultor Papieskiej Rady ds. Tekstów Prawnych prof. Ludger Mueller z Uniwersytetu Wiedeńskiego podkreślił, że procesy kościelne chronią prawa człowieka, czyniąc to w sposób pośrednio, służą podstawowym celom Kościoła. Zadaniem Kościoła jest ochrona praw człowieka na drodze administracyjnej i sądowej. Ks. prof. Andrzej Pastwa (UŚ) ukazał, jak znaczącą rolę w życiu Kościoła i w ochronie praw człowieka pełni zasada słuszności kanonicznej. Prelegent nawiązał do słynnego przemówienia Jana Pawła II z 1990 r. skierowanego do Roty Rzymskiej, w którym Ojciec św. przybliża związek między tym co pastoralne a tym co duszpasterskie. Z kolei ks. prof. zw. dr hab. Ryszard Sztychmiler (UWM, KAK) przedstawił rolę adwokata w dochodzeniu do prawdy w sprawach o stwierdzenie nieważności małżeństwa, natomiast ks. prof. zW. dr hab. Tomasz Rozkrut (UPJPII) wskazał, że w wielu sądach kościelnych przyjmuje się z zasady wszystkie skargi powodowe o stwierdzenie nieważności małżeństwa, zaś konieczne jest ich selekcjonowanie. W tej części prelekcje wygłosili ponadto ks. prof. UKSW dr hab. Jan Krajczyński (,Ochrona praw dziecka w kanonicznych procesach małżeńskich") oraz o. mgr Dariusz Lebok, doktorant z Uniwersytetu Wiedeńskiego („Prawa człowieka a przeniesienie proboszcza, który jest członkiem instytutu zakonnego, na inne stanowisko"). Następnie miała miejsce dyskusja, w której Prelegenci odpowiadali na liczne pytania postawione przez prawników świeckich (zwł. dużą aktywnością odznaczał się prof. UAM dr hab. Krzysztof Knoppek). Pytano się m.in. o to: jakie kryterium przyjmuje kanonistyka na rozróżnienie dowodów godziwych od niegodziwych?, czy nie jest ryzykowne odrzucanie skargi o nieważność małżeństwa przez sąd kościelny z przyczyn merytorycznych? (w procesie cywilnym przed sądem powszechnym odrzucenie pozwu następuje jedynie z przyczyn formalnych), czy prawidłowe są wyroki niemieckich sądów kościel- 
nych, w których za wystarczającą przyczynę nieważności małżeństwa uznano brak stopnia doktora u pozwanego?

Drugą część sesji poświęconej kanonicznemu prawu procesowemu rozpoczęło wystapienie ks. dra Martina Šimko, który scharakteryzował ochronę praw człowieka w praktyce sądów kościelnych na Słowacji. Następnie dr Seweryn Świaczny przypomniał zasady prawa kanonicznego, które chronią nieochrzczonych, zaś ks. dr Marek Zaborowski (KUL) wspomniał o uproszczonej procedurze przed sądownictwem kościelnym, tzw. ustnym procesie spornym. Kolejne referaty wygłosili reprezentanci KUL-u: mgr lic. Magdalena Kołbuc („Zasada kolegialności jako wyraz ochrony praw człowieka w kanonicznych sprawach o nieważność małżeństwa'), mgr lic. Monika Nakielska („Mediacja i możliwość jej aplikacji w procesach o stwierdzenie nieważności małżeństwa”), ks. mgr lic. Marcin Królik („Amor veritatis gwarantem pomocy stronom na etapie przedprocesowym spraw o nieważność małżeństwa”) oraz ks. dr Wojciech Witkowski (,Zakres działania stron podczas gromadzenia dokumentów w procesach kanoniczych"). W tej części obrad głos zabrali także gospodarze konferencji, a mianowicie pracownicy Katedry Prawa Kanonicznego i Wyznaniowego mgr Aleksandra Bitowt (,Odpowiedź na pozew w kanonicznym procesie o nieważność małżeństwa formą ochrony praw obojga współmałżonków"), dr Justyna Krzywkowska i mgr Monika Krzywkowska („Wymóg pewności moralnej u sędziego orzekającego w sprawach o nieważność małżeństwa") oraz przedstawiciele Studenckiego Koła Naukowego Prawników Kanonistów UWM, Ewelina Reczuch i Joanna Rybicka-Ziarko („Problem wykorzystania dowodów zdobytych w sposób niegodziwy w kanonicznym procesie o nieważność małżeństwa"). Sesję pierwszą zakończył referat mgr lic. Zofii Orłowskiej, która pełni funkcję adwokata świeckiego i kościelnego. Przedstawione zostały zasady prawa do rzetelnego procesu i jego ochrony w porządku państwowym i kościelnym. Następnie odbyła się dyskusja, w której głos zabrali: ks. prof. Wojciech Góralski (UKSW), dr Aneta Arkuszewska (UR), prof. UAM dr hab. Krzysztof Knoppek. Zainteresowanie w czasie dyskusji wzbudził temat dotyczący mediacji w prawie kanonicznym: czy sędzia w Kościele może być sam mediatorem?, jaki jest cel mediacji w procesie kanonicznym?, czy strony procesowe przed zapadnięciem wyroku o stwierdzenie nieważności małżeństwa często godzą się ze sobą? Podczas przerwy obiadowej wszyscy zgod- 
nie podkreślali, że konferencja jest dobrą okazję do posłuchania, czym zajmują się kanoniści i prawnicy świeccy.

Sesję drugą, którą poprowadził w części pierwszej ks. prof. dr hab. Ryszard Sztychmiler, rozpoczął wykład prof. UAM dr hab. Krzysztofa Knoppka na temat ochrony praw człowieka w procesie cywilnym na przykładzie prawa świadka do odmowy zeznań i odmowy odpowiedzi. Prof. Knoppek w wystapieniu polemizował z poglądami prof. dra hab. Bartosza Rakoczego w kwestii ochrony tajemnicy spowiedzi. Prelegent postawił pytanie: na jakiej podstawie sędzia w sądzie państwowym jest związany przepisami prawa kanonicznego? Kolejne referaty wygłosili: dr Joanna Studzińska (KUL) - „Prawo do wysłuchania jako jedna $\mathrm{z}$ gwarancji ochrony praw człowieka $\mathrm{w}$ postępowaniu cywilnym”, dr Paweł Cioch (KUL) - „Zwolnienie od kosztów sądowych jako prawo ubogich w postępowaniu cywilnym". Interesujący wykład wygłosił prof. zw. dr hab. Bartosz Rakoczy (UMK, KAK), który podkreślił, że „,bez watpienia w konstrukcji domniemań należy upatrywać ograniczenia prawa do sądu, oraz zasady równości wobec prawa". Następnie prelekcje wygłosili: dr Aneta Arkuszewska, dr Anna Kościółek (Uniwersytet Rzeszowski) - „Ireniczne zakończenie sporu cywilnego”, dr Edyta Gapska (KUL) - „Prawo do sprawiedliwego wyroku w postępowaniu cywilnym", mgr Katarzyna Cygan (UWM) - „Sposoby ustalania zadośćuczynienia pieniężnego za naruszenie dóbr osobistych w świetle aktualnego orzecznictwa Sądu Najwyższego oraz doktryny” oraz mgr Jerzy Akińcza (UWM) - „Udział prokuratora w ochronie stosunków o charakterze cywilnoprawnym przed sądem cywilnym". Głos w dyskusji zabrali: prof. Rakoczy, prof. Knoppek, ks. prof. Rozkrut, mgr Andrzej Kijak (UŚ), mgr Anna Franusz (UWM). Prof. Rakoczy nie zgodził się z prof. UAM Krzysztofem Knoppkiem, ponieważ Sąd Najwyższy uznaje skuteczność prawa kanonicznego, i sędzia musi posiłkować się prawem kanonicznym, aby zdefiniować pojęcie parafii czy proboszcza. Ważna jest odpowiedź na pytanie: co jest wartością chronioną? Tą wartością jest ochrona tajemnicy spowiedzi, dlatego konieczna jest życzliwa wykładnia tej wartości. Natomiast ks. prof. Rozkrut przedstawił racje natury teologicznej, które bronią wartości sakramentu spowiedzi św. Sędzia sądu okręgowego w Olsztynie postawiła wiele interesujących pytań: przepisy chronią jedynie spowiedź konfesyjna, a co z tajemnicą duszpasterską?, czy można zabezpieczyć listę grzechów przynoszonych niekiedy do konfesjonału?, co z przesłuchaniem osoby, która podsłuchała 
przypadkowo lub celowo czyjąś spowiedź? Według pani sędzi tajemnica spowiedzi św. jest chroniona w sposób niedostateczny. Podsumowując tę część sesji ks. prof. Sztychmiler podkreślił, że zarówno prawo kanoniczne korzysta z pojęć wypracowanych przez prawa cywilnego, jak i odwrotnie.

Po przerwie kawowej kontynuowano rozważania w zakresie ochrony praw człowieka w procedurze cywilnej. Przewodniczącym sesji był tym razem prof. UAM dr hab. Krzysztof Knnopek. W tej części obrad referaty wygłosili w większości pracownicy i doktoranci Wydziału Prawa i Administracji UWM: dr Magdalena Rzewuska i dr Maciej Rzewuski - „Stosowanie prekluzji dowodowej przez sąd a realizacja zasady prawdy materialnej”, mgr Hanna Frąckowiak - „Nierówne wymogi proceduralne stawiane pełnomocnikom profesjonalnym a prawo do sądu”, mgr Paweł Snopek (doktorant) - „Prawo do rozpoznania sprawy bez nieuzasadnionej zwłoki”, mgr Marzena Żulewska (Izba Skarbowa w Olsztynie) - „Ochrona prawa do dobrego imienia w sprawach o rozwód” oraz mgr Bartosz Pawlak (doktorant) - „Prawo do rzetelnego procesu sądowego a zakres orzekania Sądu Ochrony Konkurencji i Konsumentów - zagadnienia wybrane”. Ponieważ podczas każdej konferencji wielką wartość naukową ma dyskusja, po wysłuchaniu ostatniego referującego przystapiono do niej. Głos zabrali: prof. UWM dr hab. Krzysztof Knoppek, który m.in. doprecyzował wystapienie mgra P. Snopka w kwestii terminologicznej (chodziło o rozróżnienie terminów ,przerwa” i „odroczenie”). Dr Rzewuska w dyskusji wskazała, że zasada prawdy materialnej w postępowaniu cywilnym nadal istnieje, co wynika z orzecznictwa, choć została w pewnym stopniu ograniczona. Do dyskusji włączyli się także mgr A. Kijak, mgr A. Franusz i dr M. Rzewuski.

Ostatnia sesja w pierwszym dniu obrad poświęcona została ochronie praw człowieka w Trybunale Konstytucyjnym oraz w postępowaniu i procesie administracyjnym, a jej przewodniczenie powierzono ks. prof. Tomaszowi Rozkrutowi (UPJPII). Pierwszy referat wygłosiła dr Dorota Lis-Staranowicz (UWM), która przedstawiła 5 błędów kardynalnych, które popełniają profesjonalni pełnomocnicy sporządzając skargę konstytucyjną. Jak podkreśliła referentka, tylko $10 \%$ skarg spełnia wymagania formalne. Następnie prelekcje wygłosili: dr Piotr Piszczek (UWM, NSA) - ,Status uchodźcy w procedurze administracyjnej i sądowoadministracyjnej - zagadnienia wybrane", dr Maciej Gapski (KUL) - „Prawo do pomocy społecznej w orzecznictwie są- 
dów administracyjnych (wybrane zagadnienia)", dr Ewa Wójcicka (Wyższa Szkoła Zarządzania i Prawa, Wydział Zamiejscowy we Wrocławiu) -,Sądowa ochrona jednostki przed bezprawnym działaniem organów gminy”, dr Marcin Konarski (UKSW) - „Jakość wartości sądowej kontroli administracji publicznej", członkini Studenckiego Koła Naukowego Prawników Kanonistów UWM, Ilona Biedrzycka - „Odrzucenie w procedurze administracyjnej zasady ignorantia iuris nocet gwarancja ochrony praw człowieka". Ostatni referat w tym dniu wygłosił ks. dr Robert Piega (oficjał Sądu Biskupiego Diecezji Sosnowieckiej) - „Prawo człowieka do wolności religijnej w postępowaniu o wpis do rejestru kościołów i innych związków wyznaniowych i jego sądowa ochrona". Pomimo późnej godziny również po tej sesji odbyła się ciekawa dyskusja, w której udział wzięli: mgr Mikołaj Pawlak (Łódzka Izba Adwokacka, KAK), prof. UAM dr hab. Krzysztof Knoppek. Pytania dotyczyły m.in. ostatniego referatu: ile razy Ministerstwo wydało decyzje odmowne o wpis do rejestru związku wyznaniowego?, jaki jest status związków wyznaniowych działających bez rejestracji? czy istnienie związków bez stosownej rejestracji jest nielegalne czy prawnie obojętnie? Miłym elementem podsumowania pierwszego dnia obrad był wspólny wyjazd do gospodarstwa agroturystycznego na uroczystą biesiadę.

Słowo wprowadzające w drugi dzień konferencji wygłosił ks. prof. Ryszard Sztychmiler, który serdecznie powitał przewodniczącego sesji poświęconej ochronie praw człowieka w procedurze karnej, prof. UWM dr hab. Jerzego Kasprzaka, prodziekana ds. nauki WPiA UWM. Ponadto ks. prof. Sztychmiler w imieniu polskich kanonistów, Korpusu Adwokatów Kościelnych, wszystkich obecnych na konferencji złożył najszczersze gratulacje i życzenia JE bpowi Antoniemu Dziemiance $\mathrm{z}$ racji nominacji na biskupa diecezji pińskiej, aby Pan Bóg pozwolił przez wiele lat sprawować tak ważny urząd, aby tamtejsza ludność, jak najlepiej mogła realizować prawo do wolności sumienia i wyznania. Bp Dziemianko (sekretarz generalny Konferencji Katolickich Biskupów na Białorusi), który mógł przybyć dopiero w drugim dniu konferencji, wygłosił referat pt. „Ochrona danych osobowych w Kościele Katolickim na terenie dzisiejszej Białorusi w latach 19391989 jako ochrona przed ewentualnymi procesami”.

W sesji IV referaty wygłosili: dr hab. Radosław Koper (UŚ) - „Zakres ochrony prawa do prywatności na tle wywiadu środowiskowego w procesie karnym”, dr Katarzyna Kaczmarczyk-Kłak (UR) - „Instru- 
menty ochrony godności człowieka w toku postępowania karnego", dr Robert Dziembowski (UWM) - „Ochrona czci człowieka w polskim prawie karnym na tle regulacji międzynarodowych", dr Marcin Wielec (UKSW) - „Arogancja sądów a realizacja praw procesowych przez strony postępowania sądowego”, mgr Krzysztof Szczucki (UW) - „Prokonstytucyjna wykładnia prawa karnego jako instrument ochrony praw człowieka”, dr Czesław P. Kłak (UR) - „Ochrona praw pokrzywdzonego $\mathrm{w}$ toku postępowania przygotowawczego $\mathrm{w}$ świetle standardów europejskich", mgr Marta Brzezińska, prof. Danuta Tarnowska (US) - „Ochrona oskarżonego przed niesłusznym tymczasowym aresztowaniem”, mgr Maria Górska (UKSW) - „Ochrona praw człowieka w procesach o wydanie dziecka”, dr Bogna Orłowska-Zielińska, dr Krystyna Szczechowicz (UWM) - „Regulacje procedury karnej w aspekcie praw zagwarantowanych art. 6 ust. 3 EKPC" oraz mgr Karol Juszka (UJ) - „Sądowa ochrona praw człowieka w stosowaniu instytucji warunkowego umorzenia postępowania karnego". Prelegenci zwrócili uwagę na wyjątkową aktualność tematu konferencji. Wydawałoby się, że w dzisiejszych czasach sądy (monteskiuszowska trzecia władza) w prowadzonych postępowaniach działa zawsze w granicach prawa, hołdując zasadzie równouprawnienia procesowego stron z poszanowaniem wszystkich możliwych gwarancji procesowych. Autorzy zastanawiali się co jest nie tak z realizacją uprawnień procesowych stron. Prelegenci dzielili się swoimi obserwacjami zaczerpniętymi bezpośrednio z teorii, prowadzonych badań naukowych, ale także z analizy praktycznej. Głos w dyskusji zabrali: ks. prof. Sztychmiler, prof. Krzysztof Knoppek, mgr lic. Zofia Orłowska, dr Damian Gil (KUL). Pytano się m.in. o to czy aktualnie naruszana jest wolność osobista i wolność religijna na Białorusi?; czy słuszne są głosy w kwestii depenalizacji zniesławienia i znieważenia?

W czasie przerwy kawowej wielokrotnie podkreślano, że nie często zdarzają się konferencje, które w tak szerokim aspekcie obejmuja omawianą problematykę. Po przerwie kawowej kontynuowano obrady na temat ochrony praw człowieka w procesach karnych. Obradom przewodniczył ks. prof. Mieczysław Różański (UWM). W tej części konferencji prelekcje wygłosili: mgr Bogumiła Lubera (UŚ) - „Prawa człowieka a postępowanie nakazowe w polskim procesie karnym”, mgr Katarzyna Syroka (UW) - „Ochrona praw pacjenta w procesach sądowych”, dr Damian Gil (KUL) - „Prawa uczestników procesu karnego w związku z zaskarżeniem decyzji procesowych bez uruchamia- 
nia toku instancji”, mgr Nikodem Muszyński (UKSW) - „Zaniechanie ścigania w sprawie karnej skarbowej - dobrodziejstwo ustawy, organów czy kalkulacja procesowych”, dr Tomasz Sienkiewicz (KUL) - „Prawo człowieka niepełnosprawnego do obrony w postępowaniu w sprawach o wykroczenia" oraz Beata Rodak (studentka KUL) „Sprawiedliwy, czyli indywidualny wymiar kary wobec współsprawców przestępstwa” i Katarzyna Dryka (studentka KUL) -,,Postępowanie przyspieszone a ochrona podstawowych praw pokrzywdzonego i oskarżonego w polskim procesie karnym". W czasie dyskusji słuchacze pytali o powiązanie zaniechania ścigania z prawem łaski; na czym polega wewnętrzna sprawiedliwość wyroku?, jaki jest wpływ tej przesłanki na wymiar kary?

Po przerwie obiadowej odbyło się Walne Zebranie Korpusu Adwokatów Kościelnych w Polsce, któremu przewodniczył ks. prof. Ryszard Sztychmiler.

Ostatnia sesja „Ochrona praw człowieka w procesach przed trybunałami międzynarodowymi" podzielona została na dwie części. Pierwszej części przewodniczył prof. UWM dr hab. Piotr Krajewski, prodziekan ds. studiów stacjonarnych WPiA UWM. W jej ramach wykłady wygłosili: ks. mgr lic. Maciej Kubala (Papieski Uniwersytet św. Krzyża w Rzymie) - „Wolność sumienia w orzecznictwie europejskim”, dr Maciej Lubiszewski (UWM) - „Zwiększenie efektywności Europejskiego Trybunału Praw Człowieka w świetle prac nad reforma konwencyjnego systemu kontrolnego", dr Marta Szuniewicz (Akademia Marynarki Wojennej w Gdyni) - „Koncepcja ofiary pośredniej przed ETPC - na przykładzie rodzin katyńskich", dr Iwona Wrońska (UwB) - „Polska przed Europejskim Trybunałem Praw Człowieka w latach 2000-2010 - analiza statystyczna, prawna i faktyczna”. Głos w dyskusji zabrali: dr Jakub Czepek (UWM), prof. Krzysztof Knoppek, dr Izabela Gawłowicz (US), prof. Piotr Krajewski. Pytano się o osobistą refleksję na temat wyroku w sprawie katyńskiej; czy ETPC nie sformułował definicji sumienia?; czy przestępstwo obrazy uczuć religijnych w polskim kodeksie karnym nie stanowi ochrony jednokierunkowej (chroni jedynie uczucia wierzących przed niewierzącymi)? Drugiej części przewodniczył prof. dr hab. Tadeusz Jasudowicz (UWM, UMK). Referaty w tej części referaty przedstawili: dr Izabela Gawłowicz (US) - „Wbrew pozorom nadal tortury? Uwagi na tle sprawy Kupczak przeciwko Polsce przed Europejskim Trybunałem Praw Człowieka” dr Jakub Czepek (UWM) - „Początkowe zastoso- 
wanie przez ETPC procedury wyroku pilotażowego na przykładzie sprawy Broniowski przeciwko Polsce”, mgr Krystyna Ziółkowska (UWM) - „Ochrona praw pracowniczych w orzecznictwie sądów międzynarodowych i Unii Europejskiej”, mgr Mateusz Fąfara (doktorant UPJPII i PWT we Wrocławiu) - „Ochrona prawna osób wyznania chrześcijańskiego w procesach sądowych w krajach islamskich”, Katarzyna Głuch (studentka UWM) - „Prawo do poszanowania życia prywatnego i rodzinnego w świetle orzecznictwa Europejskiego Trybunału Praw Człowieka”, mgr Michał Hucał (ChAT) - „Margines oceny a ochrona wolności sumienia i wyznania w orzecznictwie ETPCz", mgr Michał Indan-Pykno (UMK) - „Polubowne załatwienie sprawy przed Europejskim Trybunałem Praw Człowieka”.

Podsumowania konferencji dokonał ks. prof. Ryszard Sztychmiler, który wyraził wdzięczność wszystkim prelegentom ciekawe wykłady. Ks. Profesor podkreślił, że referaty były selekcjonowane przez organizatorów, a mimo to ich liczba była bardzo duża. Wyrazy podziękowania skierowane zostały również do: wszystkich dyskutantów za bardzo żywe i ciekawe dyskusje, pracowników Katedry Prawa Kanonicznego i Wyznaniowego za zorganizowanie konferencji, zaś za wydanie książki do dr Justyny Krzywkowskiej, koordynatora konferencji i mgr Aleksandry Bitowt. Organizatorzy wyrazili radość, że do Olsztyna przyjeżdża coraz więcej osób.

Wieloaspektowa konferencja dotycząca najpilniejszych problemów sądowej ochrony praw człowieka zakończyła się recytacją wiersza przez jego Autora, prof. Tadeusza Jasudowicza. 